\begin{tabular}{c|l|l|l}
$\begin{array}{c}\text { Case Reports in } \\
\text { Oncology }\end{array}$ & $\begin{array}{l}\text { Case Rep Oncol 2010;3:24-29 } \\
\text { Dol: } 10.1159 / 000273112\end{array}$ & & $\begin{array}{l}\text { Published online: January 23, } 2010 \\
\text { ISSN 1662-6575 Karger AG, Basel } \\
\text { www.karger.com/cro }\end{array}$ \\
\hline
\end{tabular}

\title{
Primary Cardiac Angiosarcoma in a Young Woman
}

\author{
Aldo Pezzuto Giorgia Gencarelli Loredana Martone \\ Pierdonato Bruno Salvatore Mariotta \\ UOC Pneumologia, Azienda Ospedaliera Sant'Andrea, Seconda Facoltà di \\ Medicina e Chirurgia, Università Sapienza Roma, Roma, Italia
}

\section{Key Words}

Cardiac sarcoma $\cdot$ Lung respiratory failure $\cdot$ Pleural effusion $\cdot$ Metastasis

\begin{abstract}
A 30-year-old woman was admitted to our hospital with severe shortness of breath. A transthoracic echocardiogram showed moderate pericardial effusion with a lesion in the right atrium, confirmed by chest CT scan and cardiac RMN. Pleural and middle lobe involvement occurred within one month. Middle lobe biopsy was performed and pathological examination confirmed the diagnosis of metastatic angiosarcoma. After two months, because of recurrent pleural effusions, chemical pleurodesis was performed. Chemotherapy was started but the patient died four months after the diagnosis. This case highlights the misdiagnosis at initial clinical presentation, available diagnostic approaches and therapeutic options for cardiac angiosarcoma.
\end{abstract}

\section{Introduction}

Primary heart tumours are extremely rare in clinical practice, occurring at a frequency of $0.11-0.30 \%$ in surgical series and only $25 \%$ of them are malignant, mainly represented by sarcoma (75\%) [1-4]. The most common tumours found in the heart are due to metastasis, spreading from other organs such as the lungs, breast, pancreas and skin. Cardiac angiosarcoma is a highly aggressive tumour originating from mesenchymal tissue and endothelial subepicardium. It involves the left side of the heart more frequently than the right side [5]. It can occur at any age but the highest incidence is between the $3 \mathrm{rd}$ and 5 th decade of life [6].

Clinical presentation is usually unspecific and can vary depending on the dimension and the site of the tumour. Increasing dyspnoea, peripheral oedema, cava vein syndrome, lung oedema, arrythmia, weakness, syncopation and dizziness are the most common symptoms. Potentially mortal complications are represented by pericardial effusion and thromboembolic events $[7,8]$. 


\begin{tabular}{c|l|l|l}
$\begin{array}{c}\text { Case Reports in } \\
\text { Oncology }\end{array}$ & $\begin{array}{l}\text { Case Rep Oncol 2010;3:24-29 } \\
\text { Dol: } 10.1159 / 000273112\end{array}$ & & $\begin{array}{l}\text { Published online: January 23, 2010 S. Karger AG, Basel } \\
\text { ISSN 1662-6575 } \\
\text { www.karger.com/cro }\end{array}$ \\
\hline
\end{tabular}

The diagnosis of primary heart tumours is difficult and needs several tests such as electrocardiogram, chest X-ray, transthoracic echocardiogram, computerized spiral tomography (CT) and magnetic resonance (cardiac RMN). Cardiac angiosarcomas have usually poor prognosis due to late diagnosis and a generally rapid and fatal development. Median survival is 11 months [9-14], ranging from 2 months to 2 years.

The therapeutic approach has often a palliative purpose and includes surgery, chemotherapy and radiation therapy $[15,16]$.

\section{Case Report}

A 30-year-old woman was admitted to our department with acute dyspnoea and chest pain. The patient denied any cardiovascular or respiratory disease and reported being healthy before the symptoms occurred. Blood pressure was normal but the pulse was accelerated $(120 \mathrm{bpm})$. Heart auscultation revealed reduced heart sounds; chest examination showed hypophonesis with reduced breath sound on the left side. An electrocardiogram showed sinusal tachycardia without acute ischemic alterations. Blood test showed haemoglobin $9.5 \mathrm{~g} / \mathrm{dl}$, leukocyte count $5,360 / \mu \mathrm{m}$, platelet count $266 \times$ $10^{3} / \mu \mathrm{m}$; clotting profile, liver and renal biochemistry were normal. Arterial blood gas analysis revealed pH 7.4, $\mathrm{PaO}_{2} 59 \mathrm{~mm} \mathrm{Hg}$ and $\mathrm{PaCO}_{2} 34 \mathrm{~mm} \mathrm{Hg}$. Chest X-ray showed a mild cardiomegaly; transthoracic echocardiography revealed pericardial effusion and the presence of a hypoechogenic lesion on the left atrial wall, with normal left ventricular function. Thereafter a CT scan confirmed the finding of massive pericardial effusion and thickening of the left pericardium, no other alterations were reported (fig. 1). Pericardiocentesis was performed and $450 \mathrm{ml}$ haemorrhagic fluid were aspirated, followed by improvement of the symptoms. The patient was monitored and underwent supportive care therapy. The symptoms improved and the patient was discharged after 11 days.

Thirty days after the first presentation, a second CT scan of the chest was done to monitor the evolution of the cardiac findings. The left atrial lesion had increased in size. Multiple lung nodules and bilateral pleural effusions were found (fig. 2). Magnetic resonance imaging showed a large mass in the atrial left wall, pericardial effusion, thickening of the atrioventricular septum without endoatrial thrombus.

The patient was admitted to the cardiothoracic department and she underwent diagnostic thoracoscopy and middle lobe biopsy. The histological examination confirmed the diagnosis of pericardial angiosarcoma with pleural and lung metastasis.

The patient underwent three chemotherapy cycles with myocet, doxorubicin and ifosfamide. Because of recurrent pleural effusions, chemical talc pleurodesis was performed but remained ineffective in controlling the pleural effusion. A second-line chemotherapy with gemcitabine and docetaxel was started. After a few weeks her respiratory symptoms worsened markedly and pleural tube drainage was required on both sides (fig. 3 ). Four months after the diagnosis of primary cardiac angiosarcoma, the patient died of severe heart failure.

\section{Discussion}

The young age of the patient ( 30 years) and the rapid and fatal development of the disease are two of the peculiar aspects common to primary cardiac malignancies. The heart is rarely of interest in primary malignant tumours [1-3] and is more often involved through metastases originating from the lung or other organs $[6,7,11]$. Symptoms like clubbing, haemoptysis and chest pain can be reported but are unspecific and can mimic other heart diseases.

Cardiac angiosarcoma may have different clinical presentations, depending on the size and the site. Huang et al. [16] reported the case of a patient with a massive angiosarcoma in the right atrium, complaining of chest pain and haemoptysis as first symptoms. The authors stressed the crucial role of transoesophageal echography in the assessment of cardiac masses. 


\begin{tabular}{c|l|l|l}
$\begin{array}{c}\text { Case Reports in } \\
\text { Oncology }\end{array}$ & $\begin{array}{l}\text { Case Rep Oncol 2010;3:24-29 } \\
\text { D0I: } 10.1159 / 000273112\end{array}$ & & $\begin{array}{l}\odot \text { 2010 S. Karger AG, Basel } \\
\text { ISSN 1662-6575 } \\
\text { www.karger.com/cro }\end{array}$ \\
\hline
\end{tabular}

O'Callaghan et al. [13] described a cardiac angiosarcoma mimicking a venous thromboembolic disease and underlined the problem that this tumour is often diagnosed when it is already advanced. Other possible clinical presentations include heart failure, arrhythmia, syncope or fever with pericardial haemorrhagic effusion mimicking pericarditis $[4,5,18]$. In our case, the patient was admitted to the hospital complaining of acute dyspnoea. Physical examination revealed tachycardia, and a CT scan showed thickness of the left pericardium with pleural and pericardial effusion. The diagnosis was confirmed by the histological examination of lung biopsy obtained with thorachoscopy, performed when the patient had already developed multiple lung metastases.

Cardiac angiosarcomas with atrial localization often cause superior vena cava syndrome and peripheral oedema, while those with ventricular localization can develop heart failure symptoms or arrhythmias $[9,12]$. Abnormal electrocardiographic findings can occur, ranging from asymptomatic conduction disturbances and mild decreases of the cardiac electrical potential to fatal arrhythmias [16]. Pulmonary recurrent embolism is a quite common complication caused by heart tumours [14]. Angiosarcomas are aggressive tumours that can arise from the subepicardial layer and, in most cases, are diagnosed late after having already developed metastases.

Useful examinations for the diagnosis are: (a) echocardiography in order to evaluate ventricular cynetic, atrial wall thickening and pericardial effusion [8]; (b) CT and magnetic resonance in order to evaluate a lesion's extension and the involvement of other organs [14]. Yang et al. [8] suggested to use the two- and three-dimensional transthoracic echocardiography as the gold standard test in the assessment of a cardiac mass. Especially the three-dimensional system is an accurate non-invasive technique for defining the heart mass size, its attachment point and its relationship with other structures. Other authors underline the important role of magnetic resonance in detecting heart masses [14].

Standard surgery, adjuvant chemotherapy, and radiotherapy have been consistently unsuccessful. The surgical treatment [17], if feasible, is still considered the best option consisting of an extensive resection of the malignant mass [3]. In these cases, postsurgical radiotherapy can improve the median survival $[4,17]$. Though several chemotherapeutic regimens have been tried, chemotherapy treatment in advanced stages is ineffective and not always tolerated by the patients. Adriamycin, cisplatin, ifosfamide and paclitaxel [13, 15], docetaxel and gemcitabine are used respectively in the first- and in the second-line therapy, as in our case. They often do not bring any benefit because of a high incidence of chemoresistance $[10,15]$.

No standard adjuvant therapy has yet been described. Palliative treatments, such as talc pleurodesis and pericardial drainage, can improve the quality of life but do not interfere with the rapid development of the disease.

The prognosis of cardiac sarcoma is poor because not one of the treatments can be considered successful [9-11]. Median survival for this aggressive tumour varies between 3 and 12 months in the majority of the literature. Surgical treatment is generally associated with a better prognosis and, excluding perioperative death cases, increases the survival up to 21 months [17].

In conclusion, primary heart sarcoma is a very rare and aggressive malignant tumour, leading to death within a few months after diagnosis. It can occur at any age and should be suspected in patient with sudden unspecific heart or lung symptoms, without any particular personal or familiar pathological history. 


\begin{tabular}{c|l|l|l}
$\begin{array}{c}\text { Case Reports in } \\
\text { Oncology }\end{array}$ & $\begin{array}{l}\text { Case Rep Oncol 2010;3:24-29 } \\
\text { Dol: 10.1159/000273112 }\end{array}$ & & Published online: January 23, 2010 \\
\hline
\end{tabular}

\section{Acknowledgement}

We are grateful to Miriam Bernieri for her help in preparing the English version of the manuscript.

Fig. 1. CT scan during the first presentation (January 2008) revealed an abundant pericardial effusion with thickness of the left pericardium.

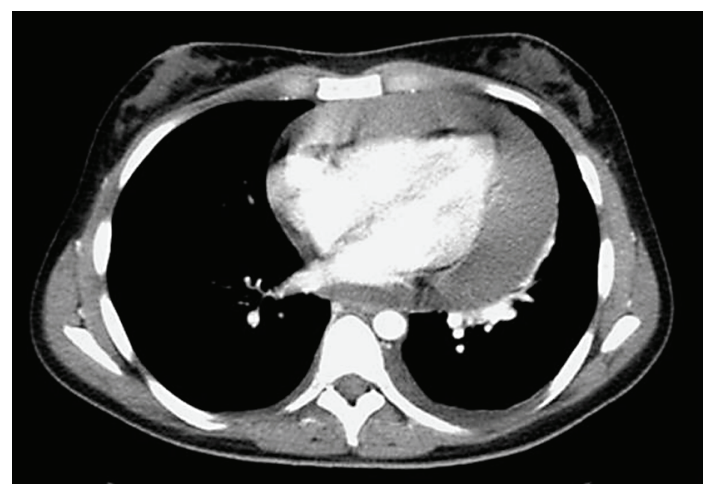

Fig. 2. Two months after admission (March 2008), CT scan showed no pericardial effusion but bilateral lung metastasis with pleural effusion.

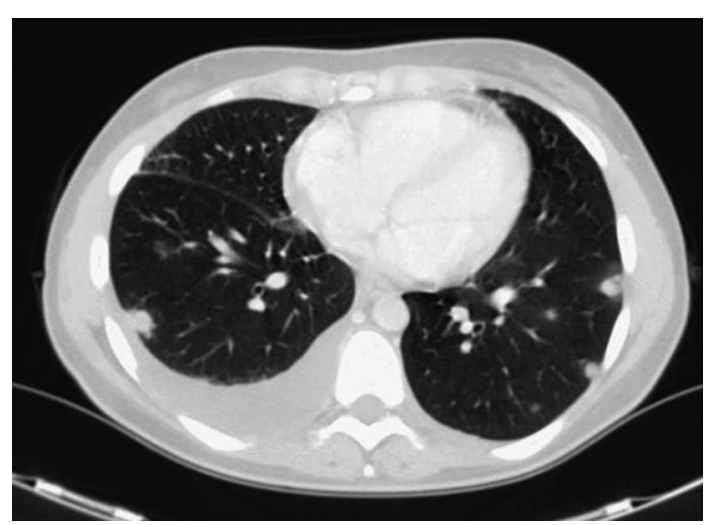




\begin{tabular}{c|l|l|l}
$\begin{array}{c}\text { Case Reports in } \\
\text { Oncology }\end{array}$ & $\begin{array}{l}\text { Case Rep Oncol 2010;3:24-29 } \\
\text { D0I: 10.1159/000273112 }\end{array}$ & Published online: January 23, 2010 & $\begin{array}{l}\text { O 2010 S. Karger AG, Basel } \\
\text { ISSN 1662-6575 } \\
\text { www.karger.com/cro }\end{array}$ \\
\hline
\end{tabular}

Fig. 3. Chest X-ray in May 2008 revealed bilateral pleural effusion, treated with drainage.

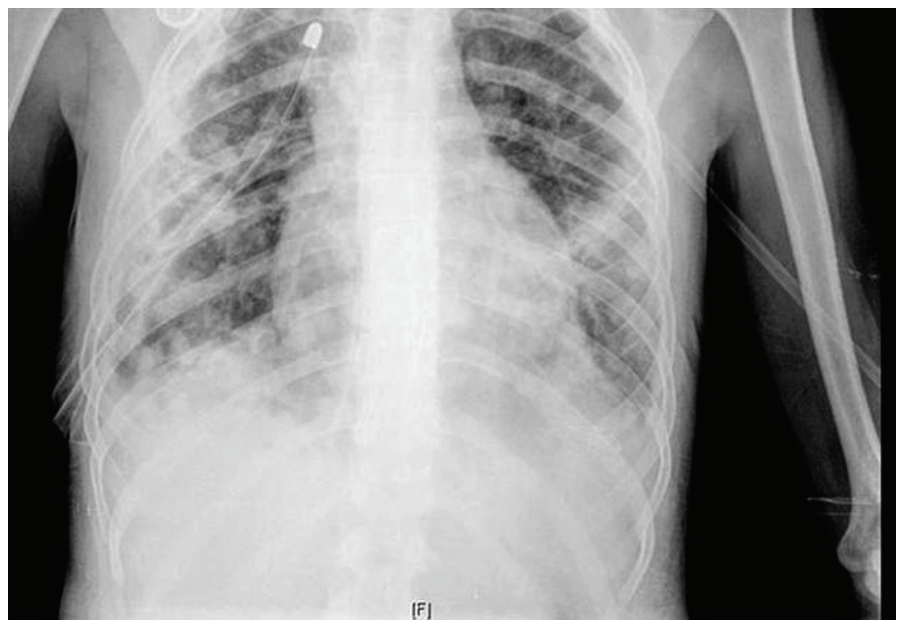




\begin{tabular}{c|l|l|l}
$\begin{array}{c}\text { Case Reports in } \\
\text { Oncology }\end{array}$ & $\begin{array}{l}\text { Case Rep Oncol 2010;3:24-29 } \\
\text { Dol: } 10.1159 / 000273112\end{array}$ & & $\begin{array}{l}\odot \text { 2010 S. Karger AG, Basel } \\
\text { ISSN 1662-6575 } \\
\text { www.karger.com/cro }\end{array}$ \\
\hline
\end{tabular}

\section{References}

1 Reynen K: Frequency of primary tumors of the heart. Am J Cardiol 1996;77:107.

-2 Molina JE, Edwards JE, Ward HB: Primary cardiac tumors: experience at the University of Minnesota. Thorac Cardiovasc Surg 1990;38:183-191.

-3 Erpolat OP, Icli F, Dogan OV, Gokaslan, Akmansu M, Erekul S, Yucel E: Primary cardiac angiosarcoma: a case report. Tumori 2008;94:892-897.

4 Moggio RA, Pucillo AL, Schechter AG, Pooley RW, Sarabu MR, Reed GE: Primary cardiac tumors: diagnosis and management in 14 cases. NY State Med J Med 1992;92:48-52.

5 Park SM, Kang WC, Park CH, Shin MS, Chung WJ, Ahn TH, Shin EK: Rapidly growing angiosarcoma of the pericardium presenting as hemorrhagic pericardial effusion. Int J Cardiol 2008;130:109-112.

6 Nicholson AG, Rigby M, Lincoln C: Synovial sarcoma of the heart. Histopathology 1997;30:349-352.

7 Burke AP, Cowan D, Virmani R: Primary sarcomas of the heart. Cancer 1992;69:387-395

-8 Yang HS, Sengupta S, Umland MM, Chandrasekaran, Mookadam F: Primary cardiac angiosarcoma evaluated with contrast two-dimensional and real-time three-dimensional echocardiography. Eur J Echocardiogr 2008;9:733-738.

$>9$ Shanmugan S: Primary cardiac sarcoma. Eur J Cardiothorac Surg 2006;29:925932.

10 O'Byrne K, Steward WP: The role of chemotherapy in the treatment of adult soft tissue sarcomas. Oncology 1999;56:13-23.

$>11$ Bittira B, Tsang J, Huynth T, Morin JF, Huttner I: Primary right atrial synovial sarcoma manifesting as transient ischemic attacks. Ann Thorac Surg 2000;69:1949-1951.

12 Schwartzman PR, White RD: Imaging of cardiac and pericardial masses. J Thorac Imaging 2000;15:265-273.

13 O'Callaghan DS, Breen DP, Young V: Angiosarcoma of the right atrium masquerading as recurrent pulmonary embolism. Thorac Cardiovasc Surg 2008;56:480-490.

14 Luna A, Ribers R, Caro P, Vida J, Erasmus JJ: Evaluation of cardiac tumors with magnetic resonance imaging. Eur Radiol 2005;15:1446-1455.

15 Sarrjeant JM, Butany J, Cusimano RJ: Cancer of the heart: epidemiology and management of primary tumors and metastases. Am J Cardiovasc Drugs 2003;3:407-421.

16 Huang J, Bouvette MJ, Zhou J, Dwyer GJ 3rd, Bhopatkar S, Bhatia A: A large angiosarcoma of the right atrium. Echo Rounds 2009;108:1755-1777.

17 Poole GV, Meredith JW, Brejer R: Surgical implications in malignant cardiac disease. Ann Thor Surg 1983;36:484-491.

18 Nayar S, Nayar PG, Cherian K: Angiosarcoma presenting as syncope. Asian Cardiovasc Thorac Ann 2008;16:154-156. 